\title{
Consumer shopping value: An investigation of shopping trip value, in-store shopping value and retail format
}

\author{
Lizhu Davis ${ }^{1}$, Nancy Hodges ${ }^{2}$
}

\begin{abstract}
Although delivering value is the key for retailers to create new competitive advantages, the literature on consumer shopping value is fragmented and findings are inconsistent. This study aimed to understand consumer shopping value in-depth by examining consumer shopping processes and experiences in two retail formats: mass merchandisers and department stores. This study conceptualizes consumer shopping value as having two components: shopping trip value and in-store shopping value. Shopping trip value is originated by fulfillment of general shopping motivations, and in-store shopping value stems from retail elements that create in-store shopping experiences that consumers have in specific retail contexts. Five shopping trip value dimensions and six in-store shopping value dimensions are identified from the in-depth interviews. The findings highlight how consumer shopping value is a complex and context specific construct.
\end{abstract}

Keywords: Consumer shopping value, Department stores, Mass merchandisers

\section{Introduction}

From the birth of the marketing concept in the 1950s, academics and businesses have sought to understand the processes and factors involved in meeting consumers' wants and needs, i.e., delivering value to consumers. Much of this work is based on the cognition, affect, and behavior (CAB) model that assumes the consumption process is a causal flow from consumer cognition to consumer affect to consumer behavior, that is, cognition variables (information seeking) determine affective responses (state of predisposition) which in turn guide behavioral effects (the choice process and purchase). Since the 1980s, the experience-oriented consumption perspective has become more prominent, particularly with the work of Holbrook and Hirschman (1982). Experiential consumption is defined as the experiential, hedonic, esthetic, and subjective dimensions of consuming (Holbrook and Hirschman, 1982; Holt, 1995). New models developed emphasize the importance of consumption experiences and argue that the outcome of consumption is value (Hirschman and Holbrook, 1986; Holbrook, 1986). Many researchers today see a broad range of consumption that includes but goes far beyond brand choice and purchase behavior. The concept of experience becomes a key element in understanding consumer behavior, as well as a fundamental factor in today's economy and the marketing of products and services (Caru and Cova, 2003).

\footnotetext{
${ }^{1}$ Department of Child, Family and Consumer Sciences, California State University, Fresno, 5300 North Campus Drive, M/S FF12, Fresno, CA 93740, USA

2 Department of Consumer, Apparel, and Retail Studies, University of North Carolina at Greensboro, 210 Stone Building, PO Box 26170, Greensboro, NC 27402, USA
} 
Consumers have become increasingly sophisticated and demanding with the availability and abundance of products, services, information, technology, as well as retail stores and channels (Terblanche and Boshoff, 2004). From the consumer's viewpoint, obtaining value is a fundamental consumption goal and pivotal to all successful exchange transactions (Holbrook, 1994). In response, many retailers are seeking to turn shopping into a high-value pursuit and are highlighting consumer value as an important source of competitive advantage (Woodruff, 1997). Despite the importance of value in creating consumer shopping experiences, existing literature on shopping value is limited. Researchers have conceptualized consumer shopping value from different perspectives and disagree upon dimensions of shopping value. Therefore, an in-depth understanding of consumer shopping value is needed.

This research seeks to understand consumer shopping value and its dimensions from a holistic view by connecting shopping motivations and processes to the ultimate outcome of shopping through exploring consumers' shopping experiences in two major shopping contexts: department stores and mass merchandisers. Department stores and mass merchandisers are of interest because they have reigned as primary retailers in the U.S. and have had a significant impact on the retail marketplace due to their size, longevity, national profile and large number of consumers they serve (Wellman, 1980; Rabolt and Miler, 2009). Department stores are large retail units, such as Macy's, Dillard's, and JCPenney in the United States, which generally carry an extensive assortment of merchandise organized into separate departments (Rabolt and Miler, 2009). Mass merchandisers are large retail discount stores such as WalMart, Kmart, and Target, which serve the mass market (Rabolt and Miler, 2009). Department stores and mass merchandisers have applied different merchandising strategies and focused on different value propositions. Department stores emphasize fashion goods with higher markups, extensive service, and a pleasant shopping experience with the value propositions of entertainment, service, and scale. Mass merchandisers, on the other hand, offer a broad range of merchandise at lower prices, provide limited service, and tend to focus on moving merchandise quickly with the hallmark value propositions of low price and shopping convenience. Therefore, comparing consumer shopping experiences at department stores and mass merchandisers may capture key dimensions of shopping value in the retail marketplace and can shed light on the relationship between retail formats and the type of shopping value that consumers gain.

By connecting shopping needs, motivations, in-store shopping experiences, and value, this study conceptualizes consumer shopping value as having two components: shopping trip value and instore shopping value. Shopping trip value is originated by the fulfillment of consumers' general shopping motivations, and instore shopping value stems from retail elements that create instore shopping experiences that consumers have in different retail contexts. Based on this conceptualization of shopping value, this study: (1) identifies key dimensions of shopping trip value based on consumers' general shopping motivations and in-store shopping value dimensions based on understanding retail elements that contribute to consumers' shopping experiences in department store and mass merchandiser contexts, thus contributing to the literature; (2) examines the effect of in-store shopping value on shopping trip value. A conceptual model of shopping value is developed based on the findings of the study to illustrate the relationship among general shopping motivations, shopping experiences, in-store shopping value, and shopping trip value. As will be discussed, consumers perceive gaining different shopping value from shopping at the retail formats studied. Findings can help retailers, and in 
this case, department stores and mass merchandisers, to better determine how to deliver value to the consumer.

\section{Theoretical framework}

\subsection{General shopping motivations}

Before the transition to the experiential consumption perspective, some scholars started to reinvestigate consumer shopping behavior by questioning consumer shopping motivations. Contrary to the traditional belief that consumers go shopping just to purchase products and/or services, Tauber (1972) argued that consumers go shopping because they experience a need and recognize that shopping activities may satisfy that need. Based on in-depth interviews, Tauber (1972) hypothesized that shopping motivations can be either personal or social. Personal motivations include role playing, diversion from daily routine, self-gratification, physical activity, learning about new trends, fashions, and innovations, and sensory stimulation; social motivations include social experiences outside the home, communication with others having a similar interest, affiliation with peer groups, obtaining status and authority, and gaining pleasure from bargaining and negotiation (Tauber, 1972). Since Tauber's seminal article (1972), many researchers have investigated consumer shopping motivations and have identified a broad range of consumer shopping motivations (e.g. Buttle and Coates, 1984; Westbrook and Black, 1985; Arnold and Reynolds, 2003). Some key shopping motivations identified in the literature are listed in Table 1.

These studies indicate that shopping is a complex consumer behavior that is either purchase related or non-purchased related. To acquire products and services, consumers may shop for product information and compare the alternatives to find the best choice (Buttle and Coates, 1984; Westbrook and Black, 1985). Arnold and Reynolds (2003) investigated consumers' hedonic shopping motivations and identified adventure shopping, gratification shopping, value shopping, social shopping, role shopping, and idea shopping motivations. Therefore, consumers shop to have fun and enjoyment through bargain hunting and socializing with family and friends, to get mental and sensory stimulation through browsing and appreciating store atmospherics, to improve personal well-being by relaxing and releasing stress, and to satisfy their curiosity about new trends and fashion (Tauber, 1972; Buttle and Coates, 1984; Westbrook and Black, 1985; Arnold and Reynolds, 2003). Overall, these studies indicate shopping is also motivated by a range of psychosocial needs that go beyond acquisition of products and services.

\subsection{Consumer shopping value}

The transition from the cognition-affect-behavior perspective of consumer behavior to the experiential perspective involves a number of changes in how consumption is viewed. One of the most important changes is the shift from a purchasing outcome to an outcome of consumer value (Holbrook, 1986; Hirschman and Holbrook, 1986). However, earlier value studies emphasized product value with a focus on the tradeoff between what is received versus what is given. This rational product and purchaseoriented perspective of value fails to recognize the irrational and sensory elements of experiential consumption (Woodruff, 1997). Since the mid-1990s, some researchers have started to investigate consumer shopping value from shopping experiences (e.g. Babin et al., 1994; Mathwick et al., 2001; Diep and Sweeney, 2008). Much of the work has focused on defining shopping value and identifying specific dimensions of shopping value. Researchers have conceptualized consumer perceived shopping value 
from different perspectives and proposed: shopping trip value (Babin et al., 1994), shopping experience value (Mathwick, et al., 2001), and store value (Diep and Sweeney, 2008).

\subsubsection{Shopping trip value}

Following Holbrook (1986), Babin et al. (1994) define value as the key outcome of consumption experiences and argue that shopping value is the overall worth of a shopping experience. As the outcome of a shopping trip, Babin et al. (1994) proposed two fundamental dimensions to shopping value, hedonic and utilitarian value. Utilitarian value relates to shopping as a work mentality, which can explain shopping trips as "an errand" or "work" and represents task accomplishment (Babin et al., 1994). In contrast, hedonic value involves fun, playfulness, and sensory reactions, which reflects shopping's potential entertainment and emotional worth and represents the immediate gratification provided by the shopping experience (Holbrook and Hirschman, 1982; Babin et al., 1994). Studies show that both shopping values affect retail outcomes and enhance such retail variables as satisfaction (Babin et al., 1994, 2005), customer share (Babin and Attaway, 2000), patronage intentions (Stoel et al., 2004; Jones et al., 2006), as well as word-of-mouth and store loyalty (Jones et al., 2006).

Although hedonic and utilitarian shopping value are useful in explaining consumer shopping behavior, Rintamaki et al. (2006) argue the importance of recognizing social shopping value. Therefore, they conceptualized total shopping value as having three dimensions, utilitarian value, hedonic value, and social value by connecting value to the fulfillment of consumer shopping needs and motivations. Based on this conceptualization, utilitarian value derives from money saving and convenience; hedonic value derives from exploration and entertainment; and social value is gained from status and self-esteem enhancement (Rintamaki et al., 2006). Their study on consumers' department store shopping experiences in Finland provides empirical evidence that social value is an independent construct rather than a sub-dimension of hedonic value.

\subsubsection{Shopping experience value and store value}

Some researchers investigated shopping value based on Holbrook's value typology and focused on the shopping process and experiences in specific shopping contexts. Holbrook (1994) identified three key dimensions of consumer value: extrinsic versus intrinsic, self-versus other-oriented, and active versus inactive. Based on the first two dimensions, value can be classified as economic value (selforiented/extrinsic), hedonic value (self-oriented/intrinsic), social value (other-oriented/extrinsic), and deontological value (other-oriented/intrinsic). Adding active versus inactive dimensions, Holbrook (1994) proposed a value typology with eight sub-dimensions of value: efficiency (convenience), excellence (quality), play, esthetics, status, esteem, ethics, and spirituality. Among those eight value dimensions, efficiency, excellence, play, and esthetics are self-oriented value (Holbrook, 1994).

Mathwick et al. (2001) investigated and assessed retail shopping experiences in the Internet and catalog shopping contexts by only focusing on the self-oriented value from Holbrook's value typology. Based on the proposed hierarchical value structure, Mathwick et al. (2001) argue that escapism and enjoyment indicate playfulness; entertainment and visual appeal indicate esthetics; shopping efficiency and product economic value indicate return on consumer investment; and service quality indicates excellence. In a similar study, Kim (2002) discussed and contrasted self-oriented consumer value experienced in the mall and Internet shopping contexts. Kim (2002) argued that playfulness is acquired through sensory stimulation, entertainment, and social interaction; esthetics derives from ambience; 
efficiency stems from convenience and resource allocation (time, effort, and money); and excellence derives from product performance and customer service. It is clearly seen that although Holbrook's value typology provides a valuable framework for analyzing shopping value in different shopping contexts, researchers disagree on the indicators or sub-dimensions of each higher level value category.

Diep and Sweeney (2008), on the other hand, argue the importance of recognizing the store value and conceptualize store value in two dimensions: hedonic and utilitarian value. Utilitarian store value is derived from the store's capability of meeting consumers' needs for getting what they want in an efficient and convenient manner; and hedonic store value stems from stores' ability to provide consumers fun, excitement, fantasy, and inspiration (Diep and Sweeney, 2008). They also connected product value and store value with shopping trip value and investigated the interrelationship among the utilitarian and hedonic dimensions of those three types of value related to shopping. The findings suggest that product value and store value contribute significantly to overall shopping trip value.

\subsubsection{A holistic view of shopping value}

These studies suggest that shopping value is a complex construct that has different categories and dimensions based on different perspectives and conceptual definitions. When comparing studies of Mathwick et al. (2001) and Kim (2002) with those of Babin et al. (1994) and Diep and Sweeney (2008), one can argue that value dimensions identified by Mathwick et al. (2001) and Kim (2002) can be seen as a combination of shopping trip value (Babin et al., 1994), product value (e.g. Sheth et al., 1991; Sweeney and Soutar, 2001), and store value (Diep and Sweeney, 2008). More specifically, sensory stimulation, entertainment, social interaction, escapism, and enjoyment are derived from the shopping trip and experience; ambience, convenience, efficiency, and customer services are derived from the store itself; and product economic value and product performance are product value. Therefore, the literature indicates that shopping trip value (Babin et al., 1994), product value (e.g. Sheth et al., 1991; Sweeney and Soutar, 2001), and store value (Diep and Sweeney, 2008) all contribute to consumer shopping value.

In order to capture shopping value to the fullest and identify all of its dimensions, a more comprehensive conceptualization of consumer shopping value is needed. To fill in the gaps in the literature, it is critical to investigate shopping value from a holistic view by recognizing its origins and emphasizing the shopping experience. So, where does value for modern consumers come from? Dewey $(1939,1966)$ stated that value is what individuals hold dear and the grounds upon which they make that determination, that is, the incorporation of effects from human experience, but also the cause and context in evaluating that experience. Dewey linked the creation of value, or human perceptions of value, to human experiences that are driven by human needs ("Some alternative conceptions", 1962). Shimp (2003) also argue that consumer needs and value are two sides of the same issue. Therefore, value derives from the fulfillment of consumers' needs and wants (Dewey, 1966; Shimp, 2003; Rintamaki et al., 2006).

It is well accepted that shopping is a complex human behavior that is motivated by a broad range of consumer needs, that is, unfulfilled consumer needs lead to different shopping motivations that motivate consumers to seek different kinds of shopping experiences that can fulfill those needs. Therefore, consumers first evaluate their shopping experiences based on how well the shopping activity fulfilled their motivations, thus forming the value perception of the overall worth of the shopping trip, which is shopping trip value as conceptualized by Babin et al. (1994). As Rintamaki et al. (2006) argue, only retailers who understand the complexity and multiplicity of shopping motivations are able to create 
and deliver shopping value to their customers. Yet, because the needs and wants of consumers shift over time and depending on the situation, it is necessary to constantly assess value and within specific contexts (Dewey, 1966). Generalizing shopping trip value into hedonic and utilitarian motivations cannot fully explain consumer shopping value as an outcome, making it important to assess consumer shopping value based on need/motivation fulfillment.

While shopping at retail stores to fulfill their needs, consumers seek different shopping experiences through interaction with products, store personnel and store environment (Terblanche and Boshoff, 2004). Retail stores create value for consumers by providing products, services and other in-store elements that consumers want and need. Therefore, consumers also evaluate their shopping experiences based on what retail stores provide leading to the fulfillment of the shopping motivations, thus forming value perceptions of in-store shopping experiences. This type of value is very close to store value as conceptualized by Diep and Sweeney (2008), and we define it as instore shopping value.

The literature is inconsistent on the dimensions of in-store shopping value, from generalized dimensions of hedonic and utilitarian value (Diep and Sweeney, 2008) to more specific ones including product performance, ambience, convenience, efficiency, and customer services (Mathwick et al., 2001; Kim, 2002). To understand instore shopping value, it is critical to recognize the in-store shopping experiences that consumers have in retail formats. The in-store shopping experience is the consumer's interaction with a store's physical surroundings, personnel, merchandise, and customer-related policies and practices (Kerin et al., 1992; Terblanche and Boshoff, 2004). Terblanche and Boshoff (2004) argue that the in-store shopping experience is a multi-dimensional construct and propose five key dimensions: personal interaction, merchandise value, internal store environment, merchandise variety and assortment, and complaint handling. Clearly there is an overlap between the in-store shopping value construct and in-store shopping experience construct. Therefore, to identify the dimensions of in-store shopping value, what consumers want from their shopping experiences in a specific context must first be identified, that is, the benefits consumers gain when shopping in different retail environments. Enhancing the in-store shopping experience, which is central to creating value perceptions in retailing, will provide retailers with opportunities to find new avenues for achieving and sustaining competitive advantage.

In summary, consumer shopping value has two components: shopping trip value and in-store shopping value. These two values derive from consumers' evaluation of their shopping experiences based on (1) how well the shopping activity fulfilled their motivations (shopping trip value) and (2) what retail stores provided that lead to the fulfillment of the shopping motivations (in-store shopping value). Only by investigating both components will we gain a better understanding of shopping value and create more satisfying shopping experiences for consumers.

\section{Methodology}

This study explores consumer shopping value from the consumer's perspective by investigating the origins of shopping value: fulfillment of shopping motivations and specific benefits consumers gain from retail stores. Shopping value is examined as it relates to two different types of retail environments: department stores and mass merchandisers. The in-depth personal interview was used as the primary method of data collection because it focuses on the participants' expression of their own experiences (Denzin and Lincoln, 1994). Open-ended interviews were conducted with sixteen participants (thirteen females and three males) ages 20-55 to explore their shopping experiences. Participants were recruited 
in the Southeastern United States at a large university as well as local churches through posters and word-of-mouth. Participant occupations were wide ranging and included students, professionals (such as engineers and office personnel), as well as homemakers, representing a diverse consumer base (see Table 2).

Interview questions were designed to solicit information from the participants about their shopping experiences. The questions focused on their general shopping motivations, shopping experiences, and benefits they gain when they shop at department stores and mass merchandisers. All interviews were audio-taped with the permission of the participants and later transcribed for analysis and interpretation. Several cycles of part-to-whole interpretive procedures were conducted to organize the raw data and to generate conceptual schemes based on the data (Spiggle, 1994; Thompson, 1997). First, using an intratext strategy, the interview data from each participant were read and coded. Second, through an intertext strategy, data were analyzed across all the interviews for the emergence of similarities and differences. Third, previously interpreted interview texts and newly developed understandings were further evaluated by moving back and forth between an intra-text and inter-text interpretive cycle. Finally, an overall holistic interpretation was generated through the combination of the researchers' frames of reference and the data (Spiggle, 1994; Thompson, 1997).

\section{Findings}

Five shopping trip value dimensions and six in-store shopping value dimensions emerged from the interview data. Shopping trip value dimensions are identified based on understanding consumers' shopping motivations and how well each retail format of interest helped consumers fulfill those motivations. In-store shopping value dimensions are identified by investigating consumers' in-store shopping experiences and what each retail format provides to deliver the shopping experiences that consumers desire. All the value dimensions are defined based on the shopping motivation literature and the value literature (see Table 3). Shopping trip value dimensions identified include: (1) functional value, (2) self-gratification value, (3) epistemic value, (4) socialization value, and (5) transaction value. In-store shopping value dimensions that surfaced include: (1) product quality value, (2) product price value, (3) product selection value, (4) in-store service value, (5) shopping environment value, and (6) shopping efficiency value. Both retail formats delivered different shopping trip and in-store shopping value to participants, and in-store shopping value influenced shopping trip value.

\subsection{Shopping trip value}

\subsubsection{Functional value}

Some participants revealed that they shop to purchase products that they either needed or wanted. That said, looking for something new and different was also revealed to be an important need. Consumers gain value from a shopping trip by getting what they want or need (Babin et al., 1994). Therefore, getting what is needed or wanted through shopping is defined as functional value.

WX: Usually I know what I need, like a pair of new pants. I go to the store, grab what I want, and then leave.

AB: I like shopping because I like to find things I need and new products that can help my life out. 
Gaining functional value, that is, fulfilling a shopping task can be very enjoyable for some participants, even if it is meeting a shopping need. Completing the job can be both challenging and rewarding.

OP: I love to shop because, first of all, we have to shop. It's sort of making something you have to do a little better. It is a new attitude. It is creative and problem solving. I like to solve puzzles. I like to solve problems. I like things that are creative. I sort of satisfy all those needs through shopping.

Participants revealed that they usually shopped at department stores to satisfy their wants, purchase a specific item for a social event or as a gift, or treat oneself with something nice. Therefore, participants gain functional shopping value from department stores.

OP: If I need to buy somebody a wedding present, that's probably where I will end up with unless I already have had an idea. Otherwise I would probably wander through for something that would make a good wedding present. If you give somebody something and it is in the box from Belk's [department store], it is a very different thing than if they know it comes from WalMart or Target.

$\mathrm{MN}$ : I shop at department stores when I want to get somebody something to represent, you know, "It is for you. I thought you would like it. It is nice. I would like you to have something you like but don't need to buy yourself."

In contrast, for the majority of participants, shopping at mass merchandisers is about satisfying their basic needs for daily life. Therefore, they gain functional value there too.

CD: To me, going to a mass merchandiser like a Wal-Mart is more about getting what I need to get or what I have to have. It's more about my needs.

EF: At a Wal-Mart you know when you get in you will find what you need. There always will be something there.

\subsubsection{Self-gratification value}

Participants revealed that shopping helps them to relax, release stress, or have a change from routine. Sometimes shopping is just an excuse to get out. Therefore, shopping's capability of improving personal well-being, that is, releasing stress and improving mood is defined as self-gratification value.

$\mathrm{FH}$ : I do it for recreation. Actually a lot of times I like to do online shopping. It's kind of having a break. I think it's relaxing. It's a way to do something different from my daily routine.

ST: If I had a very bad day, I would just go shopping and look around. Not necessarily buying anything, just looking. It helps me to release stress, I guess.

For some participants shopping at department stores is all about seeking fun, enjoyment, and relaxation. Therefore, they gain self-gratification value at department stores. In contrast, participants rarely gain self-gratification value at mass merchandisers.

EF: Uh I have fun at department stores (laughing). I may pick something up or may not. But it does not make any difference. You feel you are there for fun or entertainment. You can browse around, try out things, feel good about yourself, and then walk out. 
$\mathrm{JL}$ : When I go to department stores, I feel I am kind of more relaxed, kind of just walking around. I don't know (laughing). Maybe the atmosphere is more relaxing, maybe because I am going there more relaxed, or maybe it's a state of mind.

\subsubsection{Epistemic value}

Some participants went shopping to get inspired and find new ideas because of the exposure to new trends and fashions, new ideas, and novelty goods in the marketplace. Therefore, shopping's capability of arousing curiosity, providing novelty, satisfying a desire for knowledge, and keeping up with the newest trends and fashions is defined as epistemic value.

XY: Well, I shop to see what's interesting or innovative, and what new items they have.

MN: I like to go shopping because I like clothes, fashion, and art. I like to go just to look to see what I like or what I don't like.

Many participants shopped at department stores for inspiration. For them, department store shopping is idea shopping which can satisfy their curiosity about trends, fashion, and style. Therefore, they gain epistemic value at department stores.

OP: Lots of times when I go there, I already had my crystal, china... pretty much everything. But I am very interested to see what has been done on the table settings, interesting ways of folding a napkin or putting glasses together on the table, the use of colors... all those kinds of things, you know, good ideas in the linens department. I really enjoy looking around there.

EF: I think the value of department stores is that they put some time and effort in decorating the store, dressing the models and showing you what goes with what and what classic looks are, so that you don't have to figure those things out. You don't get that at a mass merchandiser. You have to figure it out by yourself.

Meanwhile, participants revealed that they gained epistemic value at mass merchandisers by learning about available products and novelty merchandise.

EF: Lots of times if I want a certain product and don't know what is available, I would go to a Wal-Mart first. I would look around and then I might go to somewhere else to compare.

BD: Even though it is so overwhelming to shop at mass merchandisers, it is nice even just walking through and checking out all the kitchen stuff, carpet, bedspreads, and all the lamps and picture frames.

\subsubsection{Socialization value}

Sometimes participants went shopping just to spend some time with their family or friends, not to focus on purchasing. Therefore, gaining positive shopping experiences through interaction with friends, family, salespeople, and other consumers is defined as socialization value.

$\mathrm{MN}$ : I usually go shopping with friends just to have fun and make good memories. For example, if I need something or my friend needs something, we will go together so that we can spend some together. 
QR: Right after college, my friend and I often went shopping and spent time together. We were not necessarily buying anything, but we had a good time interacting with each other. We formed a friendship in that way.

The data reveal that some participants liked to hang out with friends and family at department stores and others liked to shop at mass merchandisers in order to spend time with others. Therefore, participants can gain socialization value from shopping at either retail format.

FH: Usually when I go to department stores...uh...lot of times I have a family member with me. Usually when I go to pick up my Mom's clothing, I go with my Dad. So, it's kind of trip where he and $I$ can talk and catch up with things.

$\mathrm{MN}$ : If I need something or my friend needs something, we will go together to a mass merchandiser. It is like just to have something to do and have some time we can spend together. So, usually when we go out shopping or hang out or to relax, we just go to Target or someplace like that.

\subsubsection{Transaction value}

Some participants shop to hunt bargains because they enjoy the thrill of finding a really good deal. Therefore, transaction value is defined as the perception of psychological satisfaction or pleasure gained from getting a "deal" (Grewal et al., 1998). Transaction value is dominant in bargain hunting which provides consumers excitement and exhilaration, as well as a sense of accomplishment, pride and affirmation of intelligence (Schindler, 1989; Pooler, 2003).

ST: I guess I enjoy looking for a great bargain. I like to go to places trying to find one good bargain piece. Things like that, I enjoy it. It is the thrill of finding that one expensive piece that is really on sale.

$\mathrm{JL}$ : I feel really good when I get some real bargain. I shop at department stores every time when there is a big sale. It's kind of a high when I get a good buy.

Participants revealed that they were very likely to hunt for bargains and sales at department stores because they could find nice products at very good prices when department stores mark down their merchandise during sales and promotions. Therefore, they gain transaction value at department stores. In contrast, although the everyday low price of mass merchandisers is very appealing, participants do not gain the same kind of excitement or pleasure as in department stores when they found a real bargain.

OP: Bargain hunting is more likely to happen at department stores because it is a much higher price point to begin with. Those stores are fashion oriented, and they mark things down on a regular basis. Sometimes those markdowns can be really substantial. You cannot account for anything being there, but you have the possibility of having a great buy.

$\mathrm{JL}$ : A successful trip to department stores is when I find bargains. It is a pleasure, kind of getting high. I can get a good buy that is, getting lots of items on a small amount of money, like ten items at the price of one.

\subsection{In-store shopping value}


Participants' responses revealed six in-store shopping value dimensions based on their shopping experiences at department stores and mass merchandisers. While some in-store shopping value dimensions are common in both retail formats, others are unique to a particular format. Specifically, participants cited product price value, selection value, and shopping efficiency value as key in-store shopping value they gain at mass merchandisers, and claimed that product quality value, selection value, in-store services value, and shopping environment value are key in-store shopping values they gain at department stores.

\subsubsection{Product quality value}

Participants claimed that they gain product quality value at department stores because department stores generally carry high quality merchandise.

$\mathrm{CD}$ : I feel department stores get better quality products. They have things that are interesting to wear or use. If I bought my clothing at a Wal-Mart and I think it is a good deal, I would not treasure it as long as something I got from a department store.

IJ: Usually if I need something special to wear I go to department stores. It is usually when you need nicer things.

In contrast, participants explained that mass merchandisers do not provide good product quality value. They usually did not look for high quality products at mass merchandisers, which points to the belief that product quality offered there is lower than that of department stores.

OP: I would also have the feeling, especially, that their designers would squeeze every penny out of everything. In one way or the other, they negotiated the specification. So, no matter how it looks, it is not the same thing you will get somewhere else. I would be seriously concerned about quality.

$\mathrm{JL}$ : Well, for a broad range of products, a mass merchandiser is of lower quality. I won't buy furniture at a Wal-Mart or Kmart. But I might buy a piece of furniture in a department store. Department stores have good deals and good quality.

\subsubsection{Product price value}

The majority of participants believed that consumers do not gain good price value from department stores because of high markups. However, a few did believe that they could gain price value there because of sales and promotions.

IJ: I like the sales they [Macy's and Dillard's] have at stores. Good sales. It is always nice to get things cheaper than the original prices.

$\mathrm{FH}$ : I usually go to department stores for individual sales. It is about how much money I save.

In contrast, the majority of the participants claimed that they gain price value at mass merchandisers. Many of them expressed that they shop at mass merchandisers for everyday household needs or inexpensive solutions because of the price value.

BD: I save lots of money when shopping at mass merchandisers. Of course I find what I want, but the main reason is saving money. That is kind of nice. 
CD: If I need something cheap I would go to a Wal-Mart. I feel I pay more money for such things as socks and underwear in department stores. If my son needs some t-shirts and I know he would get dirt or paint on them... or... you know, when you really don't need nice things, I choose to go to mass merchandisers.

\subsubsection{Product selection value}

Participants believed that they gain product selection value at department stores. Department stores are more specialized, particularly in the soft goods area, with deep selections within each product category. Participants indicated that department stores have a good selection of different styles and brands, including private labels.

QR: Department stores are more specialized. It is limited in a good way. There is no wide range of products, but in each department you have a good variety of things to choose fromyas far as companies and brands. They carry their own brands which sometimes have more value than national brands. It's good that you can go to those stores for specific items you might not be able to find somewhere else.

OP: Going to department stores, you are going to have a narrower range to choose from. But, if you are looking for women's sweaters, you have a large amount to choose from, from conservative to fashion forward ones, from high price to moderate price, a lot of choice within the category.

Some participants see the department store as the provider of "one-stop fashion shop" because of its product selection value.

$\mathrm{FH}$ : They have a wider selection of clothing. I think of it as a soft goods one-stop shopping idea.

$\mathrm{GH}$ : I guess I think one of my problems is that whenever I see something, like a pair of shoes, I don't just see the shoes. I put a whole outfit with them in my head. That is good because if I'm in a department store and I see a nice pair of shoes, I can pick out a whole outfit.

At the same time, participants explained that mass merchandisers have a large variety of merchandise that covers almost every need in daily life, so that they were able to get whatever they need. Therefore, they gained good product selection value at mass merchandisers.

JL: You go to mass merchandisers and get what you need. That is very valuable.

ST: I like that when I go to a mass merchandiser I can get a lot of things I need. I think that's nice because it has a large variety of things. It is easy. It is a very convenient place to shop, especially for lots of things and lots of variety.

Some participants treated shopping at mass merchandisers as an errand. The appeal is that there are often a lot different brands available at various price points.

$\mathrm{XY}$ : I shop at mass merchandisers because they have a lot of alternatives and substitutes for you. I mean, say, if you want one brand and it is too expensive, you can check for alternatives, you know, cheap but good substitutes. 
UV: I guess they have a large variety of products, a lot of different things, and a lot of different brands to choose from. They have a higher level and lower level quality to choose from.

\subsubsection{In-store service value}

Participants cited good in-store service value at department stores. Moreover, they generally expected good service and more interaction with sales personnel at department stores.

$\mathrm{KL}$ : Department stores are usually well staffed and have good customer services. If you are looking for something, and you don't know where it is, the store personnel will help you. You don't have to wait long when you check out either. Usually there is only one person ahead of you.

OP: Well, one thing I think you do really expect to have at department stores is that you have personnel that are better trained, and they are more knowledgeable of the merchandise, more willing to go the extra mile to provide more information and help you find what you need. So the interaction you have with personnel at department stores is very different from what you have at mass merchandisers.

In contrast, participants recognized that they did not gain instore service value at mass merchandisers. However, it was an acceptable trade-off for price value.

AB: Service is less important at mass merchandisers because I do not expect a good atmosphere or great services.

$\mathrm{MN}$ : At mass merchandisers you cannot expect too much because they are so big and people working there are not necessarily doing something they love to do. It is just a job they have to have to make money.

\subsubsection{Shopping environment value}

Generally participants perceived good shopping environment value at department stores. Because of a more pleasant and relaxing shopping environment, participants were more likely to go there for relaxation and a fun shopping experience.

$\mathrm{KL}$ : Department stores are normally laid out very well. They are very clean and bright. They are just inviting. Majority of high end department stores all have a very welcoming feeling when you walk into it. You could stay there all day.

OP: If I have something I want to see at a department store, I would go, because it is pleasant. It is beautiful. I do see things that are visually interesting. I do see things that I know would give me ideas, so there is no resistance for me to do that. Interesting enough most times when I am in department stores I don't notice people around me much simply because they are not running into me, and children are not screaming at me. They are just sort of in the background. I guess that is part of what you want when you go there.

Some participants perceived poor shopping environment value at mass merchandisers. Although some still chose to shop at mass merchandisers because of the price value, others tried to avoid them because of unsatisfying shopping environment value. 
GH: I hate going to Wal-Mart. I hate shopping for anything there. But if I have to go to a grocery store I'd rather go to a Wal-Mart because I try to go cheap. The reason I do go to Wal-Mart is it is a lot cheaper and I can buy a lot more for my money.

WX: I usually don't go to Wal-Mart. I don't like Wal-Mart. I know it's cheap and has good deals. But it is too crowded. I don't like to go to a place that is too crowded.

\subsubsection{Shopping efficiency value}

For many participants, shopping at department stores is either browsing or buying something special, thus efficiency is not the value they gain. However, they gained shopping efficiency at mass merchandisers because they can go in, get what is on the shopping list, and get out quickly.

$\mathrm{KL}$ : I am not going to mass merchandisers to look for deals. I go just because it is the quickest and easiest place to go to pick up whatever I need, especially when I don't have a lot of time. I go to department stores when I have a little bit more time and I can really look for something.

AB: A large variety and large mix at mass merchandisers make me able to gather the items I need, thus achieving the task in a short amount of time, and at a lower price, that is the other side of it.

\section{Discussion and implications}

The role of value in the shopping experience has become an increasing concern to consumers and marketers (Dodds, 1991). Retailers strive to deliver customer value to differentiate and even to create competitive advantage. Although researchers have investigated consumer shopping value, there is little agreement upon the meaning of value or specific value dimensions. This study explored consumer shopping value from a holistic view, recognizing the origins of value, from satisfying consumers shopping motivations to in-store shopping experiences that consumers pursue, and considering how both are related to retail format. Two components of consumer shopping value derive from fulfilling consumers' wants and needs: in-store shopping value and shopping trip value. In-store shopping value originates from gaining specific benefits that contribute to in-store shopping experiences, and shopping value trip occurs through the fulfillment of consumer shopping motivations.

Based on five key shopping motivations that emerged from the interviews, five key dimensions of shopping trip value-functional value, self-gratification value, epistemic value, socialization value, and transaction value-were identified. Although it could be argued that self-gratification value, epistemic value, socialization value, and transaction value are more hedonic orientated, the data reveal that finding what is needed, that is, to accomplish the job, is enjoyable to some participants. Thus, it is important to point out that gaining all dimensions of shopping trip value can lead to shopping enjoyment. Generalizing shopping trip value as based simply on hedonic and utilitarian value can be problematic, because it does not capture the full picture of shopping activity. Therefore, all identified values should be regarded as independent constructs. The findings also reflect Dewey's (1966) point of view that assessment of value should be a continuous effort. For example, while Rintamaki et al. (2006) posited that social value is gained from status and self-esteem enhancement in the department store shopping context, the findings of this study suggest that social shopping value stems from socializing with family and friends while shopping. 
Participants' responses also indicate that product quality, price, selection, in-store service, shopping environment, and shopping efficiency are six key in-store shopping value dimensions. These in-store shopping value dimensions are very close to the dimensions of the in-store shopping experience construct conceptualized by Terblanche and Boshoff (2004), who suggest that in-store shopping value does affect consumers' in-store shopping experiences. Furthermore, participants perceived gaining different in-store shopping value at department stores versus at mass merchandisers, and in-store shopping value that consumers gain at each retail format affects their perception of shopping trip value. Because of high levels of selection value, especially from the deep selection of fashion goods, product quality value, in-store services value, shopping environment value, and price value from constant promotions and deals that department stores offer, participants tend to gain all five general shopping values. Meanwhile, because mass merchandisers offer the value of broad product selection that facilitate one-stop shopping experiences, excellent price value through an everyday low price strategy, as well as shopping efficiency value enhanced by store design and layout, participants shopped at mass merchandisers to get basic products for everyday needs and find out what is available in the marketplace. Some participants also take advantage of shopping there to socialize with friends and family. Therefore, functional value, epistemic value, and socialization value were the most notable shopping trip values that participants perceived as gained from shopping at mass merchandisers. Overall, participants perceived gaining functional value, epistemic value, and socialization value from both retail formats. However, they were more likely to gain self-gratification and transaction value from shopping at department stores. Thus, participants emphasized more fun and recreational experiences at department stores while pursuing functional values at mass merchandisers (see Table 3).

To illustrate the relationship among shopping motivations, instore shopping value and shopping trip value, a conceptual model was developed based on the findings of the study (see Fig. 1). As demonstrated in the model, unfulfilled needs and wants lead to shopping motivations which in turn lead consumers to different retail formats. Because of different shopping experiences at each format, consumers gain different in-store shopping values. Finally, as the outcome of a shopping experience, consumers gain shopping trip value, supporting Diep and Sweeney' finding (2008) that store value and product value contribute significantly to overall shopping trip value.

It is clear that consumer perceived shopping value is a complex construct because of the complexity of the shopping process itself. This study argues that overall shopping value includes both in-store shopping value and shopping trip value. The study contributes to the consumer perceived value literature by (1) identifying dimensions of both in-store shopping value and shopping trip value, thus extending the work of Babin et al. (1994) and Diep and Sweeney (2008), and (2) linking general shopping motivations and in-store shopping value with shopping trip value. Based on a comparison of department stores versus mass merchandisers, the conceptual model illustrates how shopping motivations and value enter into the overall shopping process for consumers. The study suggests that considering both shopping trip value and in-store shopping value captures the meaning of value to the fullest and is inclusive of the whole shopping process by providing a holistic view of consumer perceived shopping value. Distinguishing between shopping trip value and in-store shopping value provides retailers with better insight into consumer shopping behavior.

Retailers should consider both types of consumer perceived shopping value, as ignoring one or the other might lead to unpleasant shopping experiences and unsatisfied consumers. Findings from this study can help mass merchandisers and department stores looking to strengthen their competencies to 
deliver value to consumers. Although department stores offer a broader range of shopping trip value, so far, considering the ten-year growth rate of general merchandise stores (including mass merchandisers) at $10.4 \%$ versus that of department stores at $2.0 \%$, mass merchandisers have been the better success story (Standard \& Poor Industry Survey [S\&P], 2010). The findings suggest that product quality, selection, service, and in-store environment value are very important for consumers when they shop at department stores. Therefore, rather than offering lower-quality merchandise with low price points, department stores should focus on delivering the value of product quality and selection offered by fabrication, construction, and exclusivity of brands. Similarly, rather than cutting back on services to lower operation costs, department stores should emphasize service delivery and continue focusing on improving the in-store shopping environment to provide pleasant shopping experiences. Mass merchandisers, on the other hand, might want to continue focusing on satisfying consumers' basic needs by offering price value and efficiency value. However, the findings also suggest that mass merchandisers repel some consumers because of an unpleasant in-store environment.

This study focused only on consumer shopping values in the context of mass merchandisers and department stores. Therefore, future study should focus on investigating consumer perceived shopping value in other retail formats such as online shopping and mobile shopping. Model testing is another area in need of investigation. Measurement scales for general shopping value and in-store shopping value dimensions are needed. Finally, future studies may focus on applying the model within different shopping scenarios, thus providing insight to retailers for enhanced value delivery.

\section{References}

Arnold, M.J., Reynolds, K.E., 2003. Hedonic shopping motivations. Journal of Retailing 79, 77-95.

Babin, B.J., Attaway, J.S., 2000. Atmospheric affect as a tool for creating value and gaining share of customer. Journal of Business Research 49, 91-99.

Babin, B.J., Darden, W.R., Griffin, M., 1994. Work and/or fun: measuring hedonic and utilitarian shopping value. Journal of Consumer Research 20 (4), 644-656.

Babin, B.J., Lee, Y.K., Kim, E.J., Greffin, M., 2005. Modeling consumer satisfaction and word-of-mouth: restaurant patronage in Korea. Journal of Services Marketing 19 (3), 133-199.

Buttle, F., Coates, M., 1984. Shopping motives. The Service Industries Journal 4 (1), 71-82.

Caru, A., Cova, B., 2003. Revisiting consumption experience: a more humble but complete view of the concept. Marketing Theory 3 (2), 267-286.

Cox, A.D., Cox, D., Anderson, R.D., 2005. Reassessing the pleasures of store shopping. Journal of Business Research 58 (3), 250-259.

Denzin, N., Lincoln, Y., 1994. Handbook of Qualitative Research. Sage Publications, Thousand Oaks, CA.

Dewey, J., 1939. Theory of valuation. In: Neurath, O., Carnap, R., Morris, C. (Eds.), International Encyclopedia of Unified Science, vol. 2. The University of Chicago Press, Chicago, IL, pp. 1-67.

Dewey, J., 1966. Theory of Valuation. The University of Chicago Press, Chicago, IL. 
Diep, V.C.S., Sweeney, J.C., 2008. Shopping trip value: do stores and products matter? Journal of Retailing and Consumer Services 15, 399-409.

Dodds, W.B., 1991. In search of value: how price and store name information influence buyers' product perceptions. Journal of Services Marketing 5 (3), 27-36.

Grewal, D., Monroe, K.B., Krishnan, R., 1998. The effects of price-comparison advertising on buyers' perceptions of acquisition value, transaction value, and behavioral intentions. Journal of Marketing 62 (2), 46-59.

Hirschman, E.C., Holbrook, M.B., 1986. Expanding the ontology and methodology of research on the consumption experience. In: Brinbery, D., Lutz, R.J. (Eds.), Perspectives on Methodology in Consumer Research. Springer-Verlag, New York, pp. 213-251.

Holbrook, M.B., 1986. Emotion in the consumption experience: toward a new model of the human consumer. In: Peterson, R.A., Hoyer, W.D., Wilson, W.R. (Eds.), The Role of Affect in Consumer Behavior: Emerging Theories and Application. Lexington Books, Lexington, MA, pp. 17-52.

Holbrook, M.B., 1994. The nature of customer value. In: Rust, R.T., Oliver, R.L. (Eds.), Service Quality: New Directions in Theory and Practices. Sage Publications, Thousand Oaks, CA, pp. 21-71.

Holbrook, M.B., Hirschman, E.C., 1982. The experiential aspect of consumption: consumer fantasies, feelings, and fun. Journal of Consumer Research 9 (2), 132-140.

Holt, D.B., 1995. How consumers consume: a typology of consumption practices. Journal of Consumer Research 22 (1), 1-16.

Jones, M.A., Reynolds, K., Arnold, M.J., 2006. Hedonic and utilitarian shopping value: investigating differential effects on retail outcomes. Journal of Business Research 59, 974-981.

Kerin, R.A., Jain, A., Howard, D.J., 1992. Store shopping experience and consumer price-quality-value perceptions. Journal of Retailing 68 (4), 376-397.

Kim, Y.K., 2002. Consumer value: an application to mall and Internet shopping. International Journal of Retail \& Distribution Management 30 (12), 595-602.

Mathwick, C., Malhotra, N.K., Rigdon, E., 2001. Experiential value: conceptualization, measurement and application in the catalog and Internet shopping environment. Journal of Retailing 77 (1), 39-56.

Pooler, J., 2003. Why We Shop: Emotional Rewards and Retail Strategies. Praeger Publisers, Westport, CT.

Rabolt, N.J., Miler, J.K., 2009. Concepts and Cases in Retail and Merchandise Management. Fairchild Publications, New York.

Rintamaki, T., Kanto, A., Kuusela, H., Spence., M.T., 2006. Decomposing the value of department store shopping into utilitarian, hedonic and social dimensions: evidence from Finland. International Journal of Retail \& Distribution Management 34 (1), 6-24.

Schindler, R.M., 1989. The excitement of getting a bargain: some hypotheses concerning the origins and effects of smart-shopper feelings. Advances in Consumer Research 16 (1), 447-453. 
Sheth, J.N., Newman, B.I., Gross, B.L., 1991. Why we buy what we buy: a theory of consumption values. Journal of Business Research 22 (2), 159-170.

Shimp, T.A., 2003. Advertising, Promotion, and Supplemental Aspect of Integrated Marketing Communications, 6th ed. South-Western Publishing, Mason, $\mathrm{OH}$.

Spiggle, S., 1994. Analysis and interpretation of qualitative data in consumer research. Journal of Consumer Behavior 21 (3), 491-503.

Some alternative conceptions of value: a critique, 1962. The American Behavioral Scientists (pre-1986) 5(supplement), pp. 17-21.

Standard \& Poor's Industry Survey. /http://www.netadvantage.standardpoor. com/NASApp/NetAdvantage/showlndustrySurvey.do?code=reg\&date=/ reg_1107/reg_1107.htmS.

Stoel, L., Wickliffe, V., Lee, H.K., 2004. Attribute beliefs and spending as antecedents to shopping value. Journal of Business Research 57, 1067-1073. Sweeney, J.C., Soutar, G.N., 2001. Consumer perceived value: the development of a multiple item scale. Journal of Retailing 77 (2), 203-220.

Tauber, E.M., 1972. Why do people shop? Journal of Marketing 36 (4), 46-59.

Terblanche, N.S., Boshoff, C., 2004. The in-store shopping experience: a comparative study of supermarket and clothing store customers. South African Journal of Business Management 35 (4), 1-10.

Thompson, C.J., 1997. Interpreting consumers: a hermeneutical framework for deriving marketing insights from the texts of consumers' consumption stories. Journal of Marketing Research 34 (4), 438455.

Wellman, M.G., 1980. The future of discount stores. Survey of Business 16 (1), 18-20.

Westbrook, R.A., Black, W.C., 1985. A motivation-based shopper typology. Journal of Retailing 61 (1), 78-103.

Woodruff, R.B., 1997. Customer value: the next source for competitive advantage. 
Table 1

General shopping motivations.

\begin{tabular}{|c|c|c|}
\hline Author & Motivations & Motivation type \\
\hline Tauber (1972) & $\begin{array}{l}\text { The personal motives: } \\
\text { 1. Role playing } \\
\text { 2. Diversion from daily routine } \\
\text { 3. Self-gratification } \\
\text { 4. Physical activity } \\
\text { 5. Learning about new trends, fashions, and innovations } \\
\text { 6. Sensory stimulation. } \\
\text { The social motives: } \\
\text { 1. Social experiences outside the home, } \\
\text { 2. Communication with others having a similar interest } \\
\text { 3. Affiliation with peer groups, } \\
\text { 4. Obtaining status and authority } \\
\text { 5. Gaining pleasure from bargaining and negotiation. }\end{array}$ & General shopping motivations \\
\hline Buttle and Coates (1984) & $\begin{array}{l}\text { 1. To kill time } \\
\text { 2. To relax, exercise, and be stimulated } \\
\text { 3. A reflection of temperament } \\
\text { 4. To acquire information } \\
\text { 5. To take advantage of proximity to the shops } \\
\text { when a trip has been made for some other purpose } \\
\text { 6. To enjoy shopping as a social event } \\
\text { 7. To compare alternatives } \\
\text { 8. To enhance, or actually be, a special occasion }\end{array}$ & General shopping motivations \\
\hline Westbrook and Black (1985) & $\begin{array}{l}\text { 1. Anticipated utility } \\
\text { 2. Role enactment } \\
\text { 3. Negotiation } \\
\text { 4. Choice optimization } \\
\text { 5. Affiliation } \\
\text { 6. Power/authority } \\
\text { 7. Stimulation }\end{array}$ & General shopping motivations \\
\hline Arnold and Reynolds (2003) & $\begin{array}{l}\text { 1. Adventure shopping } \\
\text { 2. Social shopping } \\
\text { 3. Gratification shopping } \\
\text { 4. Idea shopping } \\
\text { 5. Role shopping } \\
\text { 6. Value shopping }\end{array}$ & Hedonic shopping motivations \\
\hline Pooler (2003) & $\begin{array}{l}\text { 1. Bargain hunting } \\
\text { 2. Shopping for others } \\
\text { 3. Shopping for dreams } \\
\text { 4. Shopping as competition }\end{array}$ & General shopping motivations \\
\hline Cox et al. (2005) & $\begin{array}{l}\text { 1. Bargaining hunting } \\
\text { 2. Browsing } \\
\text { 3. Sensory stimulation } \\
\text { 4. Being pampered } \\
\text { 5. Kinesthetic experience }\end{array}$ & Sources of shopping pleasure \\
\hline
\end{tabular}


Table 2

Selected demographic information of participants.

\begin{tabular}{lllll}
\hline No. & $\begin{array}{l}\text { Participant } \\
\text { identification }\end{array}$ & Gender & Age & Occupation \\
\hline 1 & AB & M & Late 30s & Engineer \\
2 & CD & F & Late 40s & Homemaker \\
Elementary \\
3 & EF & F & Early 50s & school \\
& & & & administrator \\
& & F & Early 20s & College student \\
4 & GH & F & Early 30s & Secretary \\
5 & J & F & Early 20s & Retail buyer \\
6 & KL & F & Early 20s & College student \\
7 & MN & F & Early 50s & Professor \\
8 & OP & F & Middle 40s & Homemaker \\
9 & QR & F & Early 20s & College student \\
10 & ST & F & Early 20s & College student \\
11 & UV & M & Late 30s & Professor \\
12 & WX & M & Late 40s & Data analyst \\
13 & XY & F & Early 30s & Secretary \\
14 & BD & F & Early 30s & Graduate \\
15 & FH & & student \\
& & F & Middle 50s & Homemaker \\
\hline 16 & JL & & & \\
\hline
\end{tabular}

Table 3

Shopping value types, dimensions, and consumers' value perception in different retail formats.

\begin{tabular}{|c|c|c|c|c|c|}
\hline Value types & $\begin{array}{l}\text { Value dimensions } \\
\text { within each value } \\
\text { type }\end{array}$ & Definition of value dimensions & $\begin{array}{l}\text { Supporting } \\
\text { literature }\end{array}$ & $\begin{array}{l}\text { Value perception } \\
\text { from department } \\
\text { stores }\end{array}$ & $\begin{array}{l}\text { Value perception } \\
\text { from mass } \\
\text { merchandisers }\end{array}$ \\
\hline \multirow{6}{*}{$\begin{array}{l}\text { In-store } \\
\text { shopping } \\
\text { value } \\
\text { (ISSV) }\end{array}$} & $\begin{array}{l}\text { Product quality } \\
\text { value }\end{array}$ & Perceived quality and expected performance of the product & $\begin{array}{l}\text { Sweeney and } \\
\text { Soutar }(2001)\end{array}$ & Yes & No \\
\hline & Product price value & Perceived monetary saving from low product prices & $\begin{array}{l}\text { Mathwick } \\
\text { et al. (2001) }\end{array}$ & Yes/no & Yes \\
\hline & $\begin{array}{l}\text { Product selection } \\
\text { value }\end{array}$ & A good range of products/services inside a retail store & $\begin{array}{l}\text { Terblanche } \\
\text { and Boshoff } \\
(2004)\end{array}$ & Yes & Yes \\
\hline & $\begin{array}{l}\text { In-store service } \\
\text { value }\end{array}$ & Perceived customer service excellence inside a retail store & $\begin{array}{l}\text { Terblanche } \\
\text { and Boshoff } \\
\text { (2004) }\end{array}$ & Yes & No \\
\hline & $\begin{array}{l}\text { Shopping } \\
\text { environment value }\end{array}$ & $\begin{array}{l}\text { Visual appeal, physically effectiveness, and overall pleasantness of the } \\
\text { retail store setting }\end{array}$ & $\begin{array}{l}\text { Terblanche } \\
\text { and Boshoff } \\
(2004)\end{array}$ & Yes & No \\
\hline & $\begin{array}{l}\text { Shopping efficiency } \\
\text { value }\end{array}$ & $\begin{array}{l}\text { The efficacy and effectiveness of getting the shopping done in a retail } \\
\text { store. }\end{array}$ & $\begin{array}{l}\text { Mathwick } \\
\text { et al. (2001) }\end{array}$ & No & Yes \\
\hline \multirow{5}{*}{$\begin{array}{l}\text { Shopping } \\
\quad \text { trip value } \\
\text { (STV) }\end{array}$} & Functional value & Getting what is needed or wanted through shopping & $\begin{array}{l}\text { Babin et al. } \\
\text { (1994) }\end{array}$ & Yes & Yes \\
\hline & $\begin{array}{l}\text { Self-gratification } \\
\text { value }\end{array}$ & $\begin{array}{l}\text { Shopping's capability of improving personal well-being, that is, } \\
\text { releasing stress and improving mood }\end{array}$ & $\begin{array}{l}\text { Arnold and } \\
\text { Reynolds } \\
(2003)\end{array}$ & Yes & No \\
\hline & Epistemic value & $\begin{array}{l}\text { Shopping's capability of arousing curiosity, providing novelty, } \\
\text { satisfying a desire for knowledge, and keeping up with the newest } \\
\text { trends and fashions }\end{array}$ & $\begin{array}{l}\text { Sheth et al. } \\
(1991)\end{array}$ & Yes & Yes \\
\hline & Socialization value & $\begin{array}{l}\text { Gaining positive shopping experiences through interaction with } \\
\text { friends, family, salespeople, and other consumers }\end{array}$ & $\begin{array}{l}\text { Terblanche } \\
\text { and Boshoff } \\
\text { (2004) }\end{array}$ & Yes & Yes \\
\hline & Transaction value & $\begin{array}{l}\text { The perception of psychological satisfaction or pleasure gained from } \\
\text { getting a "deal" }\end{array}$ & Dodds (1991) & Yes & No \\
\hline
\end{tabular}




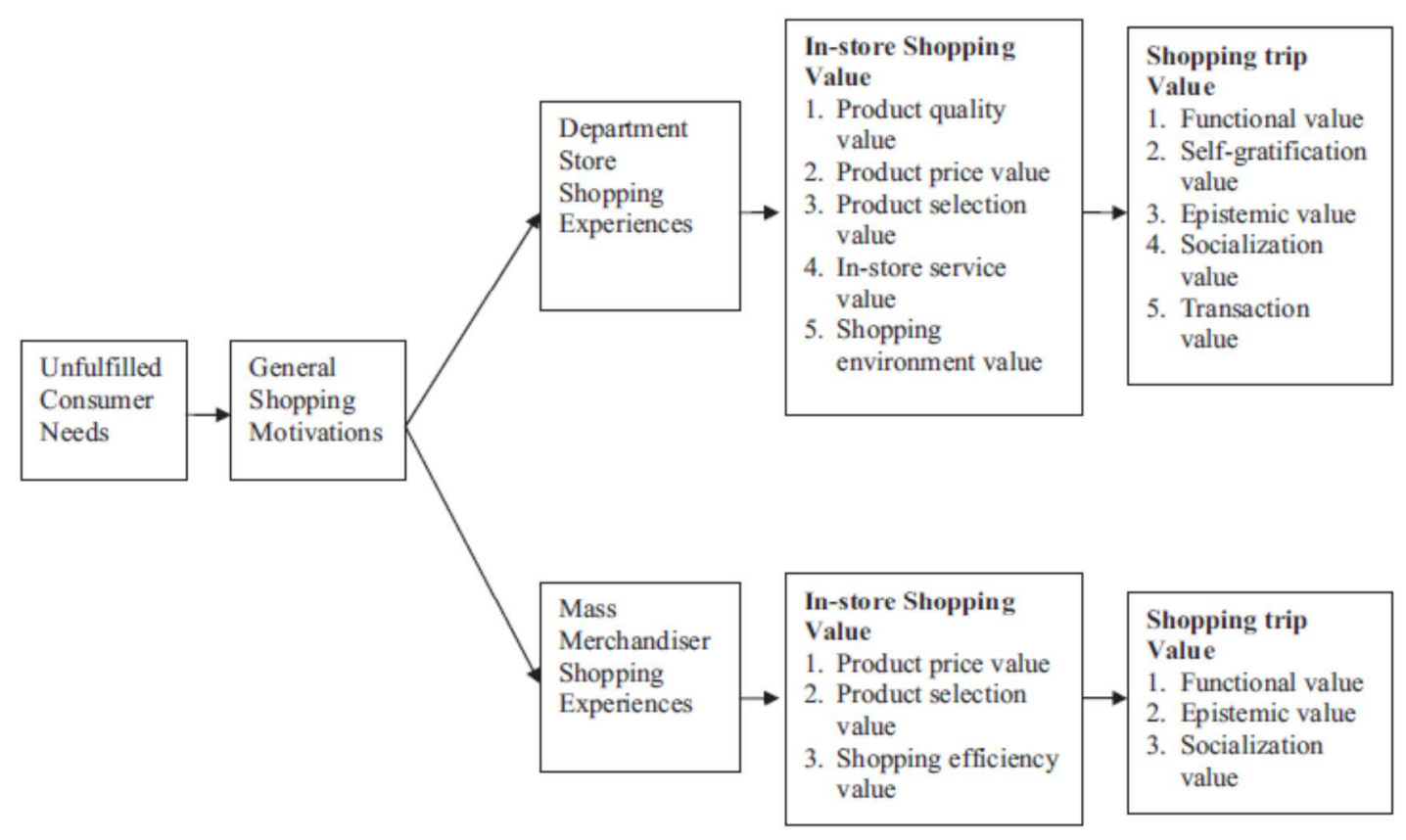

Fig. 1. Conceptual model of consumer shopping value and retail format. 